\title{
IDENTIFIKASI PERBEDAAN ELEMEN DESAIN PADA MOBIL PREMIUM DAN NON-PREMIUM Objek Studi : Mobil Toyota
}

\author{
Muhammad Irfan Nurrachman \\ Desain Interior, Fakultas Seni Rupa dan Desain \\ Universitas Kristen Maranatha \\ irfan.nurr@gmail.com
}

\begin{abstract}
Abstrak. Sebuah karya desain dirancang untuk memenuhi tujuan-tujuan yang telah ditetapkan -yaitu yang bersifat fungsional dan estetis. Dalam perancangannya, elemen-elemen desain digunakan untuk mencapai tujuan-tujuan tersebut. Namun, selain itu, desain juga berkaitan dengan masalah pemaknaan (meaning). Konsep significance berkaitan dengan pemaknaan yang melekat atau dilekatkan pada sebuah desain. Melalui tulisan ini diuraikan bahwa elemen-elemen desain pada mobil berlabel premium juga dieksplorasi untuk mencapai tujuan mengekspresikan makna premium yang dilekatkan padanya. Kajian ini membahas tentang karakteristik penggunaan elemen desain pada mobil premium dan potensinya sebagai sumber konsep bagi perancangan interior. Sesuai dengan pengertian mobil premium sebagai 'upper range products', objek studi yang digunakan dalam kajian ini adalah produk mobil Toyota yang dipasarkan di Indonesia. Dengan adanya beberapa jenis mobil yang ditawarkan dalam beberapa kategori, dimungkinkan untuk dilakukannya pembandingan terhadap berbagai elemen desain yang terdapat pada mobil dalam sebuah kategori. Pembandingan tersebut diiharapkan akan mengidentifikasi elemen-elemen desain yang menjadi pembeda antara mobil yang berada di kelompok teratas (upper range) dan mobil lainnya pada sebuah kategori. Dari hasil kajian akan tampak bahwa terdapat perbedaan kuantitas dan kualitas eksplorasi berbagai elemen desain yang melekat pada mpbil premium
\end{abstract}

Kata kunci : elemen desain, mobil, premium

Abstract. A design product is designed to satisfy the spesific goals of a problem - the functional and aesthethic ones. Along the design process, several elements of design that designer use to satistfy these goals. However, the design is also about meaning. Significance, as a concept in design, explains how forms assume meaning in the ways they are used, or the role and meaning assigned them. Through this paper, it will be shown that the design elements are used to express the premium label that attached to a car. This paper explains about the characteristic of design elements of premium cars and their potential as concept resources for interior design. As the definition of premium car as the upper-range products, this study using cars under brand Toyota that sold in Indonesia. As there are types of car in several categories, the study can identify the differences of design elements among each type of car in each category. This comparison will identify design elements that differentiate the upper-range car with another in one category. The result of this study shows there are differences in design elements quantity and quality of exploration of design elements attached to premium cars.

Keywords : design elements, car, premium

\section{Pendahuluan}

Menurut Ballast (1992), Pile (2003) terdapat berbagai elemen desain yang digunakan dalam perancangan sebuah karya desain. Melalui pengeksplorasian elemen-elemen tersebut, sebuah karya desain dirancang untuk memenuhi tujuan-tujuan fungsional dan estetis dari sebuah masalah perancangan tertentu. Dalam istilah Ching \& Binggeli (2005), sebuah desain dirancang agar functionally fit dan aesthetically pleasing. Namun sebuah karya desain menurut Heskett (2002) tidak hanya melulu dapat dilihat aspek fungsional (utility) saja. Heskett (2002) menulis bahwa pada sebuah karya desain dapat dilihat aspek significance-nya. Significance sebagai sebuah konsep dalam desain menjelaskan tentang bagaimana sebuah 
benda menerima pemaknaan sebagai mana benda tersebut digunakan, atau tentang peran dan makna yang dilekatkan pada benda-benda tersebut.

Salah satu peran/makna yang umum dilekatkan pada sebuah mobil adalah label 'premium'. Berdasarkan pengertian Kapferer (2012) tentang produk-produk premium, mobil premium dipahami sebagai mobil yang berada pada posisi 'upper range' dibandingkan mobil-mobil lainnya dalam sebuah konteks pembandingan tertentu Karena posisinya tersebut, mobil premium kemudian dapat dipahami sebagai sebuah mobil yang memiliki sebuah karakteristik tertentu yang pada dasarnya ditandai dengan tingkat kualitas tiap komponen hingga keseluruhan produk yang relatif tinggi yang pada akhirnya juga akan ditandai dengan harga jual yang relatif tinggi (Kapferer, 2012). Sedangkan Abbott (2006) memberikan istilah 'high luxury' dan 'pinnacle segment' pada pasar otomotif untuk merepresentasikan tingginya nilai jual sebuah mobil dan berkaitan dengan value creation bagi sebuah merek. Artinya, untuk sebuah 'upper range automotive product' mobil bukan sekedar alat transportasi yang dapat memindahkan seseorang dari titik A ke titik B saja, namun telah memiliki sebuah performa visual tertentu yang berkualitas.

Sebagai sebuah produk desain, desain mobil juga memiliki elemen-elemen desain. Melalui pengeksplorasian elemen-elemen tersebut, sebuah mobil dirancang sedemikian hingga memenuhi karakteristik visual yang sesuai diharapkan sesuai dengan label premium yang dilekatkan pada mobil tersebut. Dalam tulisan ini akan diidentifikasi identifikasi elemenelemen desain yang menjadi pembeda antara mobil premium dan mobil lainnya dalam sebuah kategori perbandingan tertentu. Pembandingan tersebut bertujuan untuk memperlihatkan bahwa dalam sebuah desain mobil premium terdapat penggunaan elemen-elemen desain yang berbeda dibandingkan pada desain mobil yang tidak dilabeli sebagai mobil premium. Meski menggunakan elemen-elemen desain yang sama dengan mobil non-premium, terdapat suatu karakteristik tiap elemen desain yang khas yang dimiliki oleh mobil premium.

Kajian ini dibuat sebagai bagian dari proses pembimbingan pada mata kuliah tugas akhir di program studi desain interior. Salah satu tahap yang harus dilalui oleh para mahasiswa dalam proses perancangan tersebut adalah penyusunan dan pengembangan konsep. Pentingnya konsep dalam proses perancangan dikemukakan oleh McGinty (1979) yang menyatakan bahwa “... concept are important part of architectural design. (p. 208). Menurut White (1975), pentingnya konsep dalam konteks perancangan arsitektur/interior adalah karena konsep merupakan "... general and rudimentary in character ... [and] both require and must embrace further development." (p.10). Dalam konteks pembimbingan mahasiswa, tahap pengembangan konsep ini diperlukan agar mahasiswa tersebut memiliki konsep yang dihasilkan melalui eksplorasi secara intelektual sedemikian hingga dapat digunakan untuk mengarahkan upaya perancangannya.

Salah satu dari jenis konsep adalah metafora (McGinty, 1979). Menurut McGinty (1979) menggunakan metafora berarti “... [to] identify relationship between things ... [and] the relationships are abstract rather than literal." (p. 228). Melangkapi McGinty, menurut Antoniades (1992) menggunakan metafora berarti " ... to conceive of one thing as if it were something else." (p.29). Memahami sebuah benda sebagai benda lain melalui metafora ini menurut Antoniades (1992:29) dapat dilakukan melalui upaya "(1) ... to tranfer references from one subject, (2) ... to 'see' a subject as if it were something else. Dalam konteks pembimbingan mahasiswa, berdasarkan Antoniades (1992) penggunaan metafora “... will 
offer opportunities to see a contemplated work in another light, ... will force the creator ... to come up with new interpretation. (p.30).

Dalam konteks pembimbingan yang dilakukan, mahasiswa diarahkan untuk melihat ruang interior sebagai mobil premium. Tulisan ini dimaksudkan untuk memberi contoh pada mahasiswa dalam menggunakan metafora sebagai konsep perancangan. Kategori metafora yang digunakan dalam kajian ini adalah Tangible Metaphors. Menurut Antoniades (1992), tangible metaphors adalah: "Those in which the metaphorical departure stems strictly from some visual or material character". (p.30). Melalui tulisan ini, dan belajar dari desain mobil premium, diharapkan akan memperluas wawasan mahasiswa bimbingan tugas akhir dan para desainer umumnya tentang bagaimana menggunakan dan mengeksplorasi berbagai elemen desain untuk mengekspresikan sebuah performa yang berkualitas pada sebuah karya desain, termasuk karya desain interior.

\section{Metoda}

Untuk memperoleh sebuah aspek dalam mobil premium yang dapat menjadi bagian konsep perancangan maka akan diambil sebuah kasus sebuah merek mobil. Mobil yang dijadikan objek studi adalah mobil produksi Toyota yang dipasarkan di Indonesia pada tahun 2017. Merek Toyota dipilih menjadi objek studi karena Toyota merupakan merek yang telah dikenal secara luas di Indonesia. Pada tahun 2017 Toyota berhasil berhasil menjual 371.322 mobil (34.4\% pangsa pasar) di Indonesia. Angka penjualan dan pangsa pasar tersebut merupakan yang terbesar di Indonesia pada 2017 (Gaikindo, 2018). Data ini setidaknya menunjukkan popularitas dari mobil produksi Toyota di Indonesia. Selain itu Toyota memiliki setidaknya 19 produk dan tiap produk memiliki beberapa varian (http://www.toyota.co.id). Fakta ini akan sangat membantu dalam melakukan perbandingan antara produk 'upper-range' dan yang berada dibawahnya.

Selain melakukan pengamatan pada objek studi, dilakukan juga studi literatur terhadap elemen-elemen desain. Berdasarkan Ballast (1992) terdapat beberapa elemen desain, yaitu bentuk (form), skala (scale), warna (color), tekstur (texture), pola (pattern) dan pencahayaan (light). Secara bersama tiap-tiap elemen desain ini akan membentuk suatu karakteristik visual yang khas sebuah karya desain.

Untuk mengidentifikasi elemen-elemen desain yang menjadi pembeda mobil premium dengan lainnya, akan dilakukan pembandingan terhadap elemen-elemen desain setiap mobil dalam sebuah kategori. Kategori yang dipilih dalam kajian ini ada empat : yaitu (1) hatchback, (2) sedan, (3) SUV dan (4) MPV. Kategorisasi ini sesuai dengan kategori yang ditawarkan oleh Toyota dalam media pemasaran daringnya (www.toyota.astra.co.id) . Dalam kajian ini akan diperbandingkan elemen-elemen desain antar mobil dalam tiap kategori tersebut.

Kriteria mobil premium atau upper-range yang digunakan dalam kajian ini adalah mobil dengan harga tertinggi dalam setiap kategori. Hal ini berdasarkan Kapferer (2012) yang menyatakan bahwa mobil yang menempati posisi atas (upper range) dalam sebuah kategori produk adalah produk-produk yang ditandai dengan kualitas yang relatif tinggi dari elemenelemen yang terdapat pada mobil tersebut. Berdasarkan hal tersebut, harga jual yang ditawarkan pada konsumen dipandang sebagai representasi dari kualitas yang relatif tinggi tersebut yaang terdapat pada mobil tersebut. Dengan membandingkan karakteristik elemen- 
elemen desain tersebut berdasarkan harga jualnya, maka akan terlihat karakteristik elemenelemen desain yang menjadi pembeda pada mobil premium dibandingkan dengan mobil lainnya.

Sumber data utama kajian ini adalah laman Toyota (http://www.toyota.astra.co.id). Dari laman tersebut diperoleh berbagai data tentang mobil yang ditawarkan di Indonesia, kategori, varian, harga hingga spesifikasi teknisnya. Dari laman tersebut diperoleh juga data yang memperlihatkan fitur-fitur dan performa visual untuk kepentingan permasaran. Informasi visual yang ditampilkan pada piranti pemasaran seperti laman internet, brosur atau flyer dipandang sebagai fitur dan performa yang ditawarkan pada konsumen.

\section{Kajian Literatur}

\section{a. Elemen Desain}

Elemen-elemen desain digunakan oleh desainer untuk berkomunikasi secara visual melalui karyanya dalam rangka pemenuhan tujuan fungsional dan estetisnya. Menurut Ballast (1992) terdapat enam elemen desain yaitu :

- Bentuk (form). Merupakan raut (shape) dan konfigurasi dasar dari sebuah objek. Seringkali merupakan cara pertama kali seseorang membedakan sebuah objek dengan lainnya.

- Skala (scale). Merupakan ukuran relatif dari sebuah objek dikaitkan dengan elemen lain yang telah diketahui ukurannya. Penilaian terhadap skala terjadi saat sebuah objek dilihat dalam hubungannya dengan ukuran dari objek lain.

- Warna (color). Dipandang sebagai salah satu aspek yang dipersepsi secara dominan oleh seseorang dan sebagai alat utama dalam desain.

- Tekstur (texture). Merupakan kualitas/kondisi permukaan dari sebuah material. Diperoleh dari struktur bawaan suatu material atau dari pengaplikasian pelapis (coating) diatas material tersebut.

- Pola (pattern). Merupakan pengulangan dari suatu motif dekoratif pada sebuah permukaan.

- Pencahayaan (light). Selain merupakan syarat dasar bagi terjadinya komunikasi secara visual, pencahayaan sangat kuat dalam mempengaruhi bagaimana seseorang mempersepsi sebuah objek.

\section{b. Pengertian Premium}

Elemen-elemen ruang tersebut secara secara individual maupun bersama-sama dapat dieksplorasi untuk membentuk performa visual yang diinginkan atau disampaikan, termasuk yang dibahas dalam kajian ini yaitu label premium. Berdasarkan Kapferer (2012), istilah 'premium' dalam konteks sebuah produk dan pemasarannya dapat berarti :

- Pertama, sebuah istilah yang dapat digunakan untuk menjelaskan kategori posisi (positioning) produk tersebut. Artinya, menyebutkan sebuah produk sebagai sebuah 'produk premium' dapat menggambarkan 'posisi khusus' produk tersebut dalam jajaran produk yang dijual dibawah sebuah merek tertentu. Sebuah produk 'premium' berarti bahwa produk tersebut berada 'di papan atas' (upper-range). Jadi untuk dapat memahami 
ke-premium-an sebuah produk, harus melihat dan membandingkannya dengan jajaran produk lainnya dalam merek (brand) yang sama.

- Kedua, istilah 'premium' berkaitan dengan sebuah merek (brand). Merek (brand) berfungsi sebagai 'wadah' atau konteks bagi memahami 'ke-premium-an' sebuah produk. Artinya, menyebut sebuah produk sebagai produk premium berarti berbicara tentang posisi 'papan atas' dari sebuah merek (brand). Namun menurut Kapferer (2012) - dalam bidang pemasaran - sebuah produk yang diposisikan di 'papan atas' dari sebuah merek (brand) tidak serta merta dapat diterima sebagai sebuah produk premium. Ke-premium-an sebuah produk begantung juga pada reputasi mereknya. Jika dikaitkan dengan pengertian pertama tadi, sebuah produk premium diistilahkan oleh Kapferer (2012) sebagai "upperrange branded product" (h. 44).

- Ketiga, ke-premium-an sebuah produk berkaitan dengan suatu karakteristik tertentu. Menurut Kapferer $(2012,2013)$ terdapat beberapa karakteristik yang menggambarkan kepremium-an sebuah produk. Dalam Luxury, Fashion and Premium Positioning Triangle, Kapferer (2012:32) menulis kriteria ke-premiuman sebuah produk sebagai berikut : (1) merupakan produk yang menawarkan 'Quality/Price ratio', (2) pembelian sebagai investasi, (3) menonjolkan performa (performance), (4) merupakan sebuah produk yang dapat dibandingkan (comparable) dengan produk premium lainnya berdasarkan sebuah kriteria yang sama (bandingkan dengan kemewahan sebuah produk yang tidak dapat dibandingkan dengan kemewahan produk lainnya) dan (5) produk premium menyiratkan sebuah keseriusan pada sebuah hal (bandingkan dengan sikap modis/mengikuti mode yang cenderung berubah-ubah).

Menurut model Kano (dalam Abbott, et. al., 2006) konsumen memiliki dua harapan terhadap suatu produk yang disebut berkualitas, (1) yang diekspresikan oleh kondisi pemenuhan fisik (aspek pemenuhan tujuan-tujuan fungsional) dan (2) yang diekspresikan oleh kepuasan pengguna. Abbott et. al. (2006) juga menulis bahwa dalam pasar mobil premium terdapat berbagai aspek saling berkaitan. Abbott et. al. (2006:1) menulis bahwa “... brand associations -personal beliefs, values and emotions, and brand identity..." dapat menjadi keuntungan komersial. Jadi dalam konteks kajian ini, merumuskan konsep perancangan desain interior yang terinspirasi dari mobil premium dapat menjadi sebuah titik tolak perancangan yang baik karena mobil premium sendiri telah memiliki karakter desain yang telah melampaui tingkat fungsional.

Berbagai fitur desain dalam produk otomotif dapat mempengaruhi persepsi pengamat. Chen et. al. (2007) dalam studinya menuliskan hasil kajiannya yang menyatakan bahwa kombinasi dari empat fitur desain sebuah mobil yaitu front grill, headlights, overall profile dan side vents dapai dipersepsi secara berbeda pula oleh para pengamat. Dari kombinasi keempat fitur desain tersebut, terdapat satu elemen yang lebih menonjol dari elemen lain dalam mengungkapkan sebuah ekspresi emosional tertentu. Dengan demikian, elemen-elemen visual dari sebuah mobil -termasuk mobil premium- dapat jadikan sumber konsep yang kemudian dapat dipindahkan ke dalam perancangan interior melalui metoda tangible metaphors.

\section{c. Kasus : Mobil Toyota}

Dalam lamannya, mobil-mobil yang ditawarkan oleh Toyota dikelompokkan terbagi kedalam tujuh kategori. Yaitu hatchback), sedan, multi purpose vehicle/MPV, sport utility 
vehicle/SUV, commercial, sport, hybrid. Dalam kajian ini, kategori yang digunakan akan dibatasi pada 4 kategori saja yaitu : hatchback, sedan, MPV dan SUV. Tidak seperti empat kategori tersebut, ketiga kategori lainnya tidak digunakan karena : (1) kategori sport hanya menawarkan 1 produk sehingga tidak dimungkinkan dilakukan perbandingan, (2) kategori commercial dan hybrid sama-sama menawarkan produk dengan bentuk, kegunaan dan kapasitas penumpang yang berbeda, sehingga tidak dapat dilakukan perbandingan antar
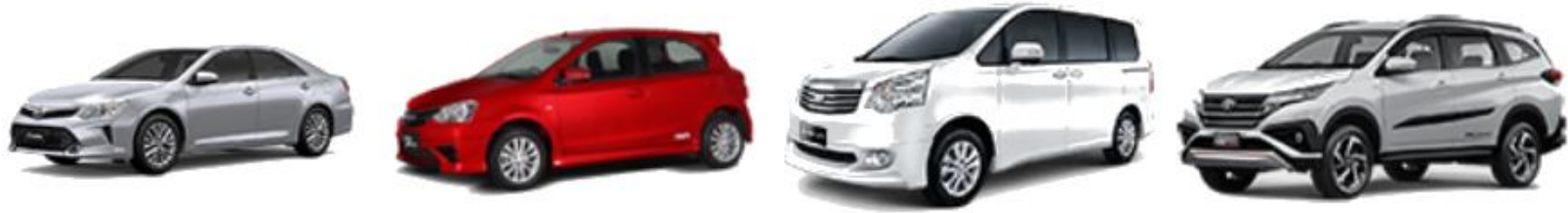

produk dalam kategori tersebut.

\section{Gambar 1. Kategori Mobil : Sedan, Hatchback, MPV dan SUV}

Dalam setiap kategori tersebut, Toyota menawarkan beberapa produk, yaitu :

- Kategori hatchback ditawarkan 3 produk, yaitu : Agya, Etios dan Yaris.

- Kategori sedan 3 produk, yaitu Vios, Altis dan Camry

- Kategori multi purpose vehicle/MPV 8 produk, yaitu Calya, Avanza/Veloz, Sienta, Innova, NAV1, Voxy, Alphard dan Vellfire

- Kategori sport utility vehicle/SUV 3 produk, Rush, Fortuner, Land Cruiser

Dalam setiap produk, Toyota menawarkan beberapa varian. Perbedaan tiap varian tersebut adalah pada fitur yang ditambahkan. Fitur yang ditambahkan tersebut tidak merubah produknya secara mendasar. Perbedaan lainnya adalah pada harga. Pada dasarnya, semakin banyak fitur yang ditambahkan, semakin tinggi harga jual yang ditawarkan.

\section{Temuan dan Analisis}

Pada bagian sebelumnya telah diuraikan bahwa label premium pada sebuah produk berkaitan dengan harganya (Kapferer 2012). Produk premium memiliki 'Quality/Price Ratio', artinya tingkat kualitas produk yang ditawarkan sebanding dengan pula dengan harga yang ditawarkan. Produk premium ditawarkan dengan dengan harga tinggi karena memiliki kualitas/performa teknis dan visual yang tinggi. Jadi harga jual yang ditawarkan juga merupakan konsekuensi dari kualitas/performa visual yang tinggi pula.

Berdasarkan informasi yang ditawarkan kepada konsumennya, berikut adalah uraian tentang tiap elemen desain.

\section{a. Bentuk}

Berdasarkan Ballast (1992), bentuk (form) merupakan raut (shape) dan konfigurasi dasar dari sebuah objek. Ballast (1992) menyatakan bahwa bentuk seringkali merupakan cara pertama kali seseorang membedakan sebuah objek dengan lainnya. Dalam empat kategori yang digunakan sebagai objek studi ini, penjelasan tentang bentuk untuk tiap-tiap kategori mobil dibedakan berdasarkan bentuk, kegunaan utama dan kapasitas penumpangnya. Keempat kategori tersebut adalah : 
- Sedan, adalah sebuah jenis mobil penumpang dengan tiga kompartemen, satu kompartemen untuk mesin, satu untuk kabin penumpang dan dan satu untuk bagasi. Bagian untuk penumpang terdiri dari 2 baris tempat duduk dengan kapasitas sampai dengan 5 orang. Kegunaan utama adalah untuk mengangkut penumpang.

- Hatchback, adalah sebuah jenis mobil penumpang dengan dua kompartemen berbasis sedan, satu kompartemen untuk mesin, satu untuk kabin penumpang dengan pintu bagasi yang menyatu dengan kaca belakang. Bagian untuk penumpang terdiri dari 2 baris tempat duduk dengan kapasitas sampai dengan 5 orang. Kegunaan utama adalah untuk mengangkut penumpang.

- $M P V$, adalah sebuah mobil multi fungsi dengan dua kompartemen, satu kompartemen untuk mesin, satu untuk kabin penumpang dengan pintu bagasi yang menyatu dengan kaca belakang. Bagian untuk penumpang terdiri dari 3 baris tempat duduk dengan kapasitas sampai dengan 7 orang. Kegunaan utama adalah untuk mengangkut penumpang dan barang

- $S U V$, adalah sebuah jenis mobil penumpang dengan dua kompartemen, satu kompartemen untuk mesin, satu untuk kabin penumpang mobil penumpang yang dibangun diatas kerangka truk ringan. Memiliki hingga 3 baris tempat duduk dengan kapasitas sampai dengan 7 orang. Kegunaan utama adalah untuk mengangkut penumpang pada medan yang lebih berat dari jalan biasa.

Dari pengamatan terhadap objek studi pada tiap kategori, semua mobil memiliki konfigurasi dasar sesuai deskripsi diatas. Tidak tampak ada perbedaan konfigurasi dasar antar mobil termahal dan termurahnya pada setiap kategori. Namun walaupun memiliki konfigurasi dasar yang sama setiap mobil dalam satu kategori memiliki ciri visual yang dapat dibedakan satu dengan lainnya. Artinya, perbedaan elemen desain bentuk terdapat pada aspek yang lebih dalam dari bentuk/konfigurasi dasarnya. Berdasarkan Ching \& Binggeli (2005) aspek yang lebih dalam tersebut dapat merujuk pada sub elemen dari bentuk yaitu garis dan bidang. Dalam hal ini, bentuk/raut mobil premium dengan yang lainnya dibedakan pada level yang lebih detail yaitu pada garis dan bidang yang terdapat pada mobil-mobil terebut. Hal ini dapat berarti karakteristik kontur dari sebuah garis dan outline dari sebuah bidang.

\section{b. Skala}

Dengan mengurutkan harga jual produk Toyota berdasarkan harganya untuk tiap kategori, maka diperoleh tabel yang memperlihatkan perbedaan dimensi dari mobil-mobil tersebut (Tabel 1)

\begin{tabular}{|c|r|r|r|r|}
\hline Produk & \multicolumn{1}{|c|}{$\begin{array}{c}\text { Harga }(\mathrm{Rp}) \\
\mathrm{x} 100,000\end{array}$} & Panjang $(\mathrm{mm})$ & \multicolumn{1}{|c|}{ Lebar (mm) } & \multicolumn{1}{|c|}{ Tinggi (mm) } \\
\hline Hatchback & 132.0 & 3600 & 1620 & 1520 \\
\hline Agya & 151.0 & 3775 & 1695 & 1475 \\
\hline Etios & 232.4 & 4115 & 1700 & \multicolumn{2}{c|}{ Sumber: toyota.astra.co.id } \\
\hline Yaris & & &
\end{tabular}

Tabel 1 Ukuran mobil kategori hatchback

\begin{tabular}{|l|l|l|l|l|}
\hline Produk & Harga $(\mathrm{Rp})$ & Panjang $(\mathrm{mm})$ & Lebar $(\mathrm{mm})$ & Tinggi $(\mathrm{mm})$ \\
\hline
\end{tabular}




\begin{tabular}{|c|r|r|r|r|}
\hline \multicolumn{2}{|c|}{ Sedan } & \multicolumn{1}{|c|}{$\times 100,000$} & & \\
\hline Vios & 276.20 & 4410 & 1700 & 1475 \\
\hline Altis & 429.60 & 4620 & 1776 & 1460 \\
\hline Camry & 587.8 & 4825 & 1825 & 1470 \\
\hline
\end{tabular}

Tabel 2 Ukuran mobil kategori sedan

Sumber: toyota.astra.co.id

\begin{tabular}{|c|r|r|r|r|}
\hline Produk & $\begin{array}{c}\text { Harga }(\mathrm{Rp}) \\
\mathrm{x} 100,000\end{array}$ & Panjang $(\mathrm{mm})$ & \multicolumn{1}{|c|}{ Lebar (mm) } & Tinggi (mm) \\
\hline MPV & & & 1655 & 1600 \\
\hline Calya & 135.1 & 4070 & 1660 & 1695 \\
\hline Avanza/Veloz & 190.2 & 4190 & 1695 & 1795 \\
\hline Sienta & 233.7 & 4235 & 1850 & 1795 \\
\hline Innova & 298.7 & 4735 & 1655 & 1850 \\
\hline NAV1 & 407.4 & 4600 & 1735 & 1835 \\
\hline Voxy & 446.0 & 4710 & 1850 & 1895 \\
\hline Alphard & 904.7 & 4915 & 1850 & 1895 \\
\hline Vellfire & 1055.1 & 4930 & & \\
\hline
\end{tabular}

Tabel 3 Ukuran mobil kategori $M P V$

Sumber: toyota.astra.co.id

\begin{tabular}{|c|r|r|r|r|}
\hline Produk & \multicolumn{1}{|c|}{$\begin{array}{c}\text { Harga }(\mathrm{Rp}) \\
\mathrm{x} 100,000\end{array}$} & Panjang $(\mathrm{mm})$ & \multicolumn{1}{|c|}{ Lebar $(\mathrm{mm})$} & \multicolumn{1}{c|}{ Tinggi $(\mathrm{mm})$} \\
\hline SUV & & & & 1745 \\
\hline Rush & 239.9 & 4420 & 1840 & 1850 \\
\hline Fortuner & 467.3 & 4705 & 1970 & 1945 \\
\hline Land Cruiser & 1944.5 & 4950 & & \\
\hline
\end{tabular}

Tabel 4 Ukuran mobil kategori $S U V$

Sumber: toyota.astra.co.id

Berdasarkan data-data diatas, pada elemen desain skala terdapat perbedaan dimensi keseluruhan mobil antara mobil termurah dan termahal untuk setiap kategori. Secara umum, semakin mahal sebuah mobil semakin besar dimensi keseluruhan mobil tersebut. Pada seluruh kategori terdapat kecenderungan bahwa ukuran panjang dan lebar mobil cenderung semakin besar sesuai dengan peningkatan harga mobil tersebut. Secara khusus, pada kategori MPV dan SUV tinggi mobil juga meningkat seiring peningkatan harga mobil. Hal itu merupakan kebalikan kecenderungan yang terdapat pada kategori hatchback/sedan. Namun 
dari data diatas, tampak bahwa dimensi sebagai sub elemen dari skala digunakan untuk menggambarkan harga dari sebuah produk mobil.

\section{c. Warna}

Dengan membuat daftar warna eksterior standar mobil maka diperoleh gambar berikut :

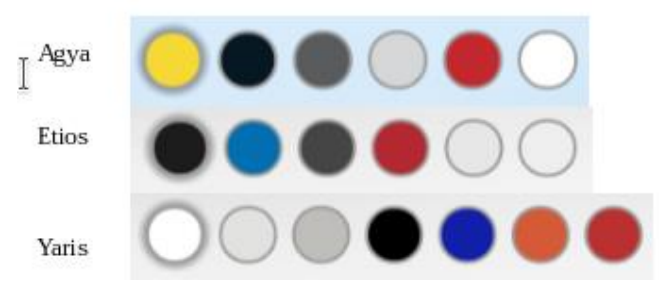

Sumber : toyota.astra.co.id Gambar 2 Warna-warna Kategori Mobil Hatchback

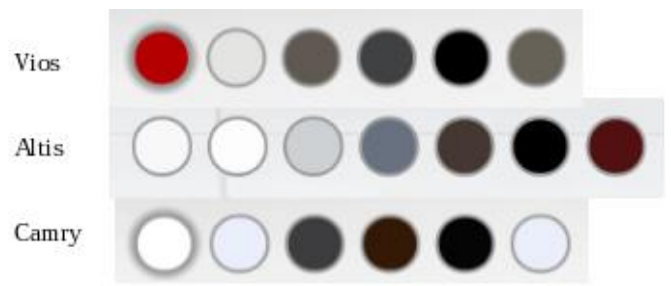

Sumber : toyota.astra.co.id Gambar 3 Warna-warna Kategori Mobil Sedan

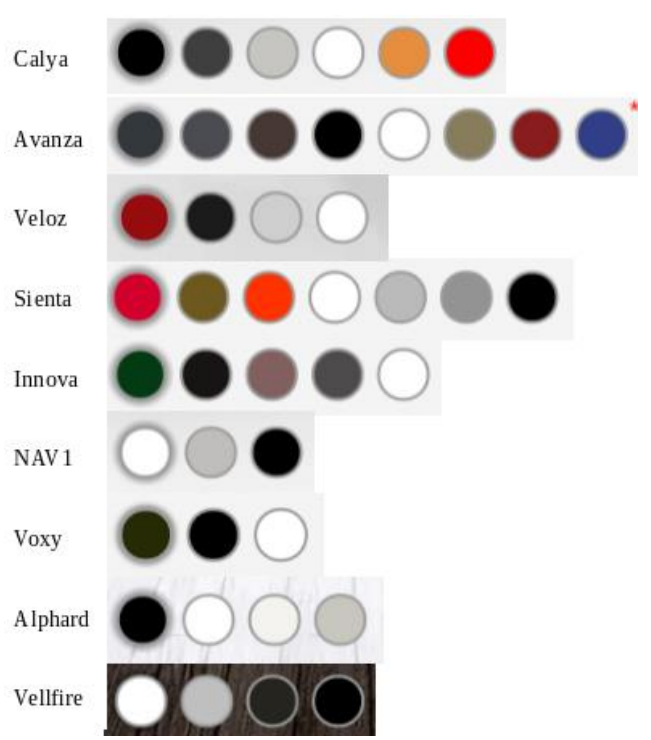

Gambar 4 Warna-warna Kategori Mobil MPV

Sumber : toyota.astra.co.id 


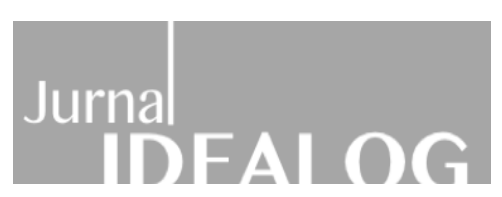

Jurnal I DE A L O G

Ide dan Dialog Indonesia

Vol.3 No.1, April 2018

ISSN Cetak 2477 - 0566

ISSN Elektronik 2615-6776

Sumber : toyota.astra.co.id

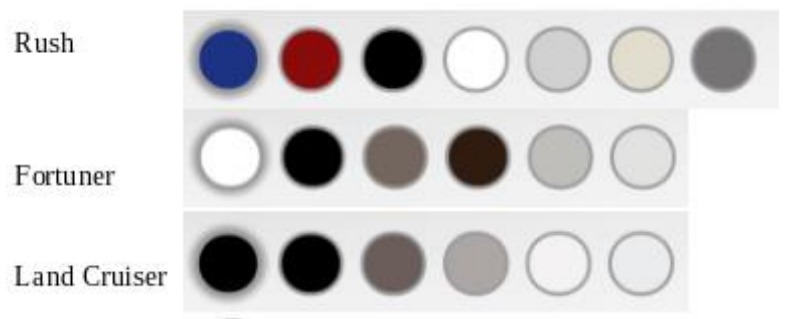

Gambar 5 Warna-warna Kategori Mobil SUV

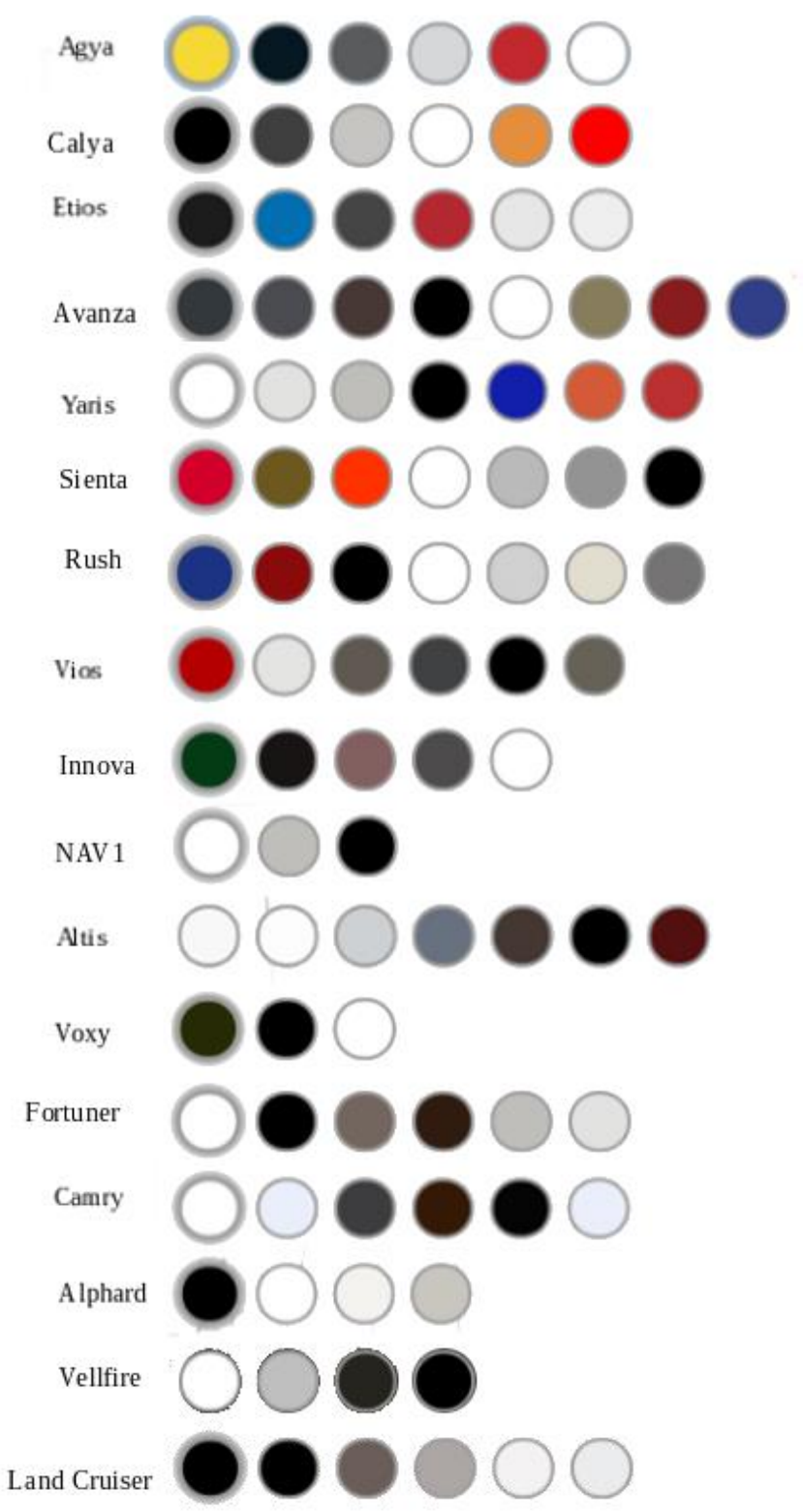

Sumber : toyota.astra.co.id

Gambar 6 Warna-warna Seluruh kategori Mobil Objek Studi 
Gambar 2, 3, 4 dan 5 masing-masing merupakan daftar warna yang ditawarkan di kategori hatchback, sedan, MPV dan SUV yang diurutkan mulai dari harga terendah tiap kategorinya. Pada kategori hatchback, hal yang menarik adalah bahwa tidak ada perbedaan signifikan pada pola penggunaan warna baik pada mobil harga terendah maupun yang termahal. Hal yang menonjol adalah, terdapat hue yang paling terang yang digunakan pada mobil dengan harga terendah (Gambar 2). Sedangkan pada kategori sedan, tampak bahwa dua produk termahal menawarkan skema pilihan warna yang cenderung menonjolkan gradasi hitamputih. Hanya pada mobil termurahnya memiliki sebuah warna berbeda (Gambar 3). Pada kategori $M P V$, pola penggunaan warna yang tampak adalah bahwa empat produk termurah dlam kategori ini memiliki warna yang berbeda dengan lima produk termahal. Pada lima produk termahal warna yang ditawarkan relatif merupakan gradasi hitam-putih dibandingkan empat produk sisanya (Gambar 4). Sedangkan pada kategori $S U V$, kecenderungan warna yang ditawarkan mirip dengan kategori sedan, yaitu bahwa dua produk termahal menawarkan skema pilihan warna yang cenderung menonjolkan gradasi hitam-putih. Hanya pada mobil termurahnya memiliki sebuah skema pilihan warna berbeda (Gambar 5).

Jika keseluruhan produk objek studi dibandingkan (Gambar 6), maka tampak sebuah pola bahwa 8 produk dimulai dari harga termurah cenderung menawarkan warna yang relatif lebih bervariasi dibandingkan dengan 9 produk dengan harga yang lebih mahal. Kelompok pertama tersebut cenderung menawarkan skema hue yang relatif bervariasi dibandingkan dengan kelompok kedua yang cenderung menawarkan skema warna grey-shade. Pola ini mirip dengan pola yang terdapat pada kategori sedan, MPV dan SUV, dan berbeda dengan yang terlihat pada kategori hatchback yang memiliki harga rata-rata mobil yang relatif lebih murah dibandingkan dengan harga rata-rata mobil di kategori sedan, $M P V$ dan $S U V$ (Rp 171.8 juta vs Rp 431.2 jt, Rp 801.9 juta dan 883.9 juta).

\section{d. Tekstur dan Pola}

Perbedaan penggunaan elemen desain tekstur dan pola pada objek studi terutama tampak bagian interior kabinnya. Pada bagian luar mobil, kualitas permukaan didominasi oleh cat mobil dengan tekstur mengilap (glossy). Tekstur tersebut tidak berbeda pada mobil dengan harga terrendah dan tertinggi ditiap kategorinya. Namun di interior kabin, mobil dengan harga tertinggi ditiap kategorinya memiliki tekstur dan pola yang dihasilkan dari material plastik, kayu, kulit dan karpet. Pada harga terrendah, ketiga tekstur dan pola yang dihasilkan ooleh ketiga material tersebut tidak tampak. Di mobil dengan harga terrendah disetiap kategori didominasi oleh plastik, karpet dan kain. 


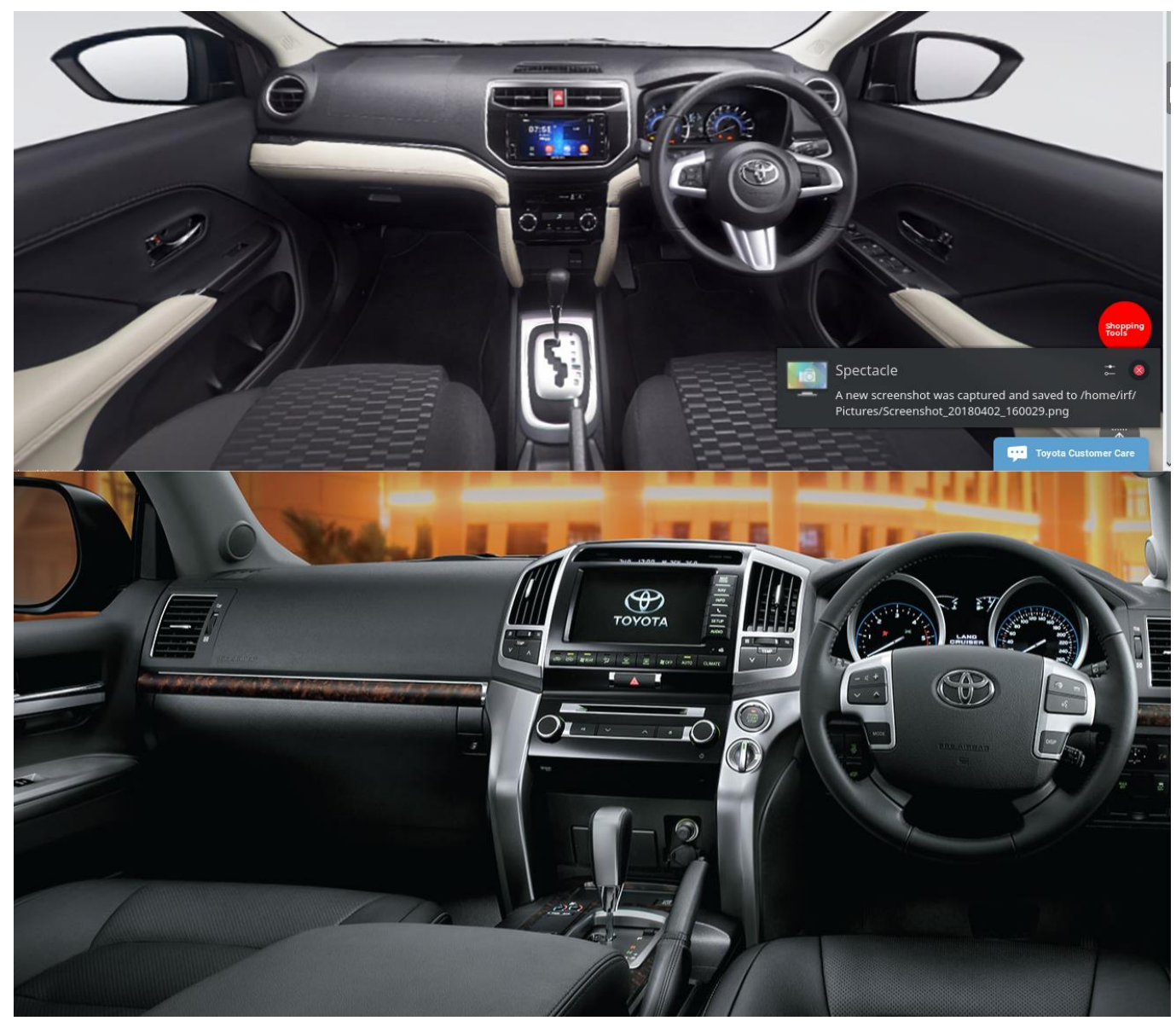

Sumber : toyota.astra.co.id Gambar 7 Desain Dashboard Toyota Rush (atas) dan Toyota Land Cruiser (bawah)

\section{e. Pencahayaan}

Perbedaan utama penggunaan elemen desain pencahayaan pada obyek studi tampak pada sumber-sumber dan efek pencahayaan yang terdapat pada kabin. Perbedaan yang tampak mencolok adalah fitur pencahayaan yang ditawarkan oleh Toyota Voxy, Aphard dan Vellfire. Ketiga produk 'upper range' di kategori MPV tersebut menawarkan : colored ceiling illumination, sun/moon roof dan sun shade. Dari perspektif eklemen desain, fitur tersebut adalah salah satu perbedaan elemen desain pencahayaan. Selain itu, Toyota Alphard dan Vellfire beberapa fitur lampu yang lebih bersifat fungsional seperti foot step lamp yang tidak dimiliki pada mobil dengan harga yang lebih rendah. 

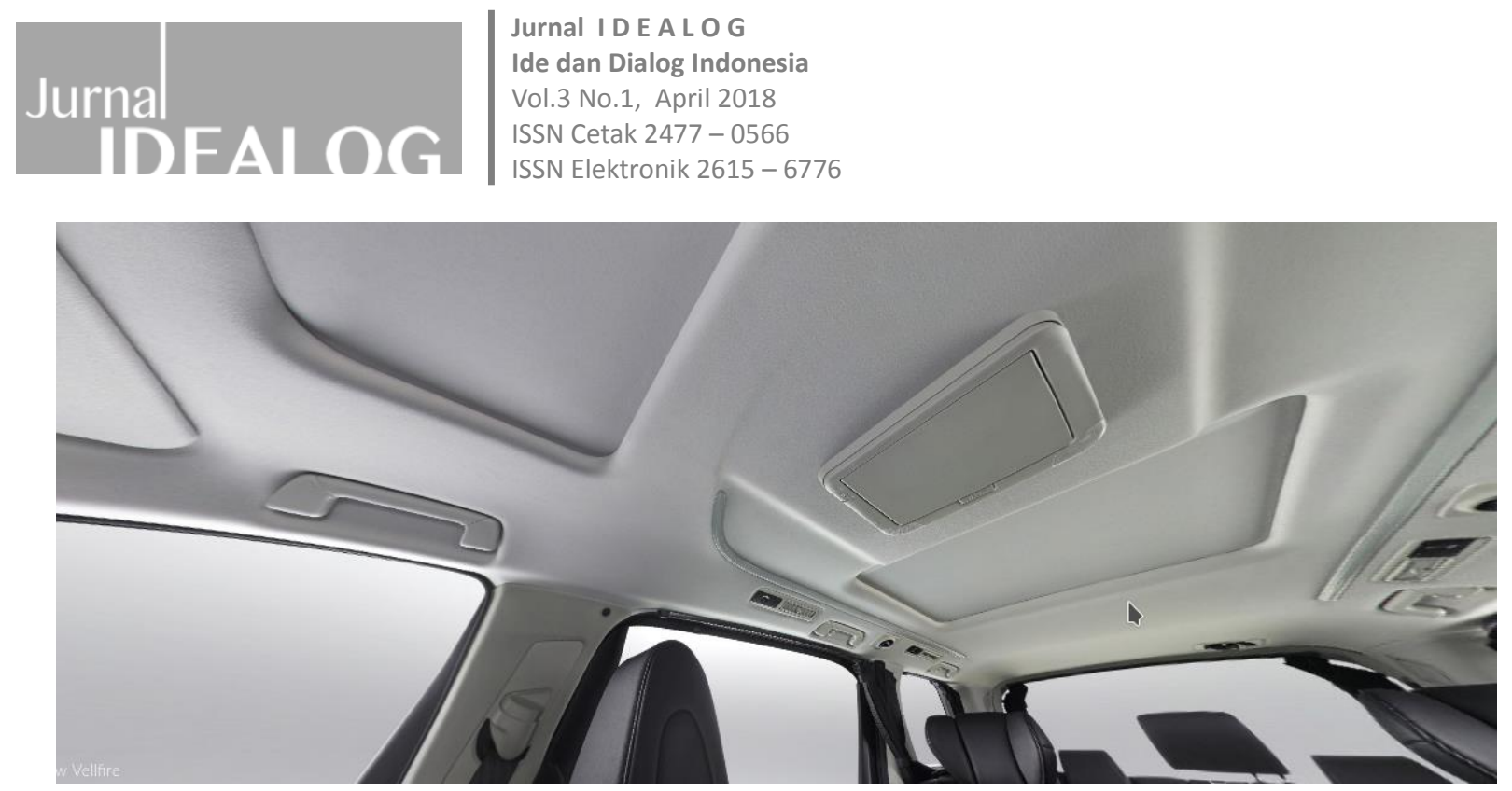

Gambar 8 Fitur moon/sun roof

Sumber : toyota.astra.co.id

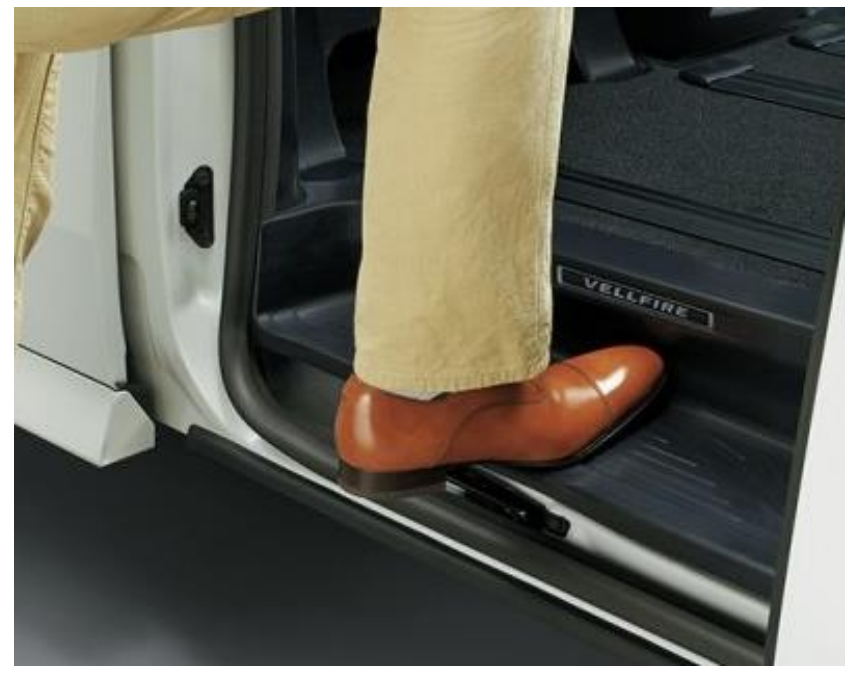

Sumber : toyota.astra.co.id

Gambar 9 Foot step illumination

\section{Kesimpulan}

Cara mengaplikasikan berbagai elemen desain pada mobil-mobil Toyota yang ditawarkan di Indonesia terlihat saat mobil-mobil tersebut dikategorisasi berdasarkan jenisnya dan diurutkan berdasarkan harganya. Jika produk premium didefinisikan sebagai 'upper-range product', maka berdasarkan kategorisasi dan pengurutan tersebut tampak bahwa terdapat perbedaan pada sebagian besar elemen desainnya. Kecuali pada elemen desain bentuk, mobil 'upper-range produk' memiliki kuantitas dan kualitas eksplorasi yang lebih besar. Jadi, dalam konteks kajian ini yaitu proses pembimbingan mahasiswa tugas akhir, dari hasil kajian ini mahasiswa dapat mengeksplorasi lebih lanjut berbagai elemen desain yang terdapat pada mobil-mobil 'upper-range product'.

Pengamatan lebih jauh dan detail terhadap elemen desain ini diperlukan untuk mengurai secara lebih mendetail kuantitas dan kualitas eksplorasi yang dilakukan pada 'upper-range product'. Tidak hanya dari apa yang ditawarkan oleh produsen, namun juga membedah secara lebih detail pada tiap produknya mengingat media pemasaran tidak sepenuhnya 
menginformasikan hal tersebut. Dengan demikian, pemahaman bahwa elemen estetis dapat dieksplorasi untuk mengekspresikan label premium pada 'upper-range product' dapat tercapai.

\section{Daftar Pustaka}

[1] Abbott, Marcus., Shackleton John P., Guest, Peter., Jenkins, Melinda -June. (2006) Engineering emotional product identities in high-luxury vehicles. 5 th. International Conference on Design and Emotion, Chalmers University of Technology, Gothenburg, Sweden. September 2006.

[2] Ballast. David. K. (1992). Interior Design Reference Manual. Belmont, Professional Publication, Inc

[3] Chen, Lin-lin., Kang, Hsien-Chang, Hung, Wei-Ken (2007). Effects of design Features on Automobile Styling Perceptions. 15 th International Assocoation of Societies of Design Research (IASDR07). The Hongkong PolytechnicUniversity, November 2007

[4] Ching, F.D.K \& Binggeli, C. (2005). Interior Design Illustrated. Second Edition. New Jersey, John Wiley \& Sons, Inc.

[5] Gaikindo, 2018. Indonesian Automobile Industry Data. https://www.gaikindo.or.id/indonesian- automobile-industry-datal . Diakses pada 18 Februari 2018

[6] Heskett, John. (2002). Design. A Very Short Introduction. New York, Oxford University Press.

[7] Kapferer, J. N \& Bastien, V. (2012). The Luxury Strategy : Break the Rules of Marketing to Build Luxury Brand. London, Kogan Page.

[8] McGinty, Tim. (1979). Concepts in Achitecture. Dalam Snyder, James C.,Catanese, Anthony J. (ed) Introduction to Architecture. New York, McGraw-Hill

[9] KBBI Daring (2017). Available at https://kbbi.kemdikbud.go.id/. Accessed :2017-0925

[10] Pile, John F. (2003). Interior Design. Third Edition. Prentice-Hall, Inc., New Jersey

[11] PT Toyota Astra Indonesia. (2016). Available at http://www.toyota.astra.co.id/. Accessed : 2017-09-25

[12] White, Edward T. (1975). Concept Sourcebook. A Vocabulary of Architectural Form. Architectural Media Ltd, Tucson 